О.Г. БУРДО, д-р техн. наук, професор, зав. кафедрою процесів апаратів та енергетичного менеджменту,

I.B. БЕЗБАХ канд. техн. наук, докторант,

О.В. ЗИКОВ канд. техн. наук, доцент кафедри процесів апаратів та енергетичного менеджменту Одеська начіональна академія харчових технологій

\title{
АОСЛІДЖЕННЯ ПРОЦЕСУ СУШІННЯ В РЕКУПЕРАТИВНІЙ ЗЕРНОСУШАРЦІ
}

Проведено аналіз парку сушильної техніки. Показано, щзо проблему зниження енергоспоживання процесу сушіння може бути вирішено за рахунок адресної доставки енергї до зерна. Розглянуто апарати на базі термосифонів для сушіння дисперсних харчових матеріалів. Приведено конструкцію рекуперативної зерносушарки, в якій реалізується адресна доставка енергї до зерна за допомогою теплових труб. Оригінальна конструкція конденсаційної ділянки теплової труби забезпечує не тільки передачу енергї до шару сипучого матеріалу, але й ефективне його перемішування. Наведено результати експериментальних досліджень рекуперативної зерносушарки. В результаті досліджень виявлено, шьо вид ліній сушіння не характерний для сушіння пшениці в конвективних сушарках. У зв'язку з тим, щуо відбувається постійний розігрів зернового потоку швидкість сушіння постійно зростає й лише наприкінці прочесу стабілізується. Аналіз вологовмісту й температури повітря на виході із сушарки показує, щуо у порівнянні із зерносушаркою ДСП-32, повітря на виході з рекуперативноі зерносушарки має набагато більиу відносну вологість і вологовміст шчо робить його близьким до точки фазового переходу. Крім того витрати повітря в конвективних сушарках і рекуперативній відрізняються на порядки. Після аналізу розподілу теплової енергї̈ в зерносушарках з'ясовано , щуо в порівнянні з конвективним сушінням у рекуперативної сушарки більша частина енергї $(69,4 \%)$ затрачається на випаровування вологи, шуо підтверджує білішу ефективність використання енергії в рекуперативній сушариі. Аналіз параметрів відпрацььваного повітря рекуперативної зерносушарки, показує, шзо з'являється реальна можливість використання тепла конденсації вологого повітря для попереднього нагрівання зерна. Таким чином можна повернути в зерновий потік значну частину енергї, щуо була витрачена в сушильній шахті.

Ключові слова: термосифони, дисперсні матеріали, зерно сушіння, енергоефективність.

Для сушіння зерна в Україні застосовують сушильні апарати різних типів. Найбільше поширення й найбільшу продуктивність мають шахтні зерносушарки. В Україні на долю цих сушарок припадає більше $80 \%$ діючих установок із продуктивністю від 2 до 50 т/год. Шахтні сушарки більшої продуктивності (до 120 т/год) використовують у термінальних елеваторах США й Канади, але для європейських промислових установок найбільш характерна продуктивність від 2 до 10 т/год [1].

Аналіз парку сушильної техніки в Україні показує, що в 48\% випадків експлуатуються застарілі шахтні агрегати вітчизняного виробництва. Досить високий відсоток використання шахтних сушарок закордонного виробництва - 38\%. Близько $10 \%$ підприємств використовують вітчизняні й закордонні сушарки, що дає можливість порівнювати їх технологічні й експлуатаційні характеристики, а також більш ефективно забезпечувати сушіння різних культур. Близько 4\% аграріїв використовують інші типи сушильного встаткування, наприклад мобільні сушарки, а також агрегати колонкового типу [2].

Iз закордонних шахтних сушарок використовуються американські агрегати (45\%), італійські й польські зерносушарки (14\%), турецькі (7\%). Близько $21 \%$ зерносховищ оснащені зерносушарками інших типів і країн-виробників. Причому вдосконалення ділянки сушіння у виробників перебуває тільки на 3 місці (16\%).

Але застосування шахтних зерносушарок приводить до досить високих енерговитрат - 5 МДж/кг і вище. 3 другого боку, незалежно від конструкції сушарки кожний вид зерна для знімання вологості зерна на $1 \%$ вимагає однакової кількості теплоти. Отже, у конструкторів різних сушарок існує однакове завдання - донести теплоту до зерна, зробивши втрати мінімальними. Чим краще вирішене таке цільове завдання, тим менше експлуатаційні витрати на сушіння.

Для рішення проблем адресної доставки енергії до зерна, зниження енергоспоживання процесу сушіння, підвищення екологічності процесу розроблена конструкція рекуперативної сушарки (рис. 1).

Сушарка містить шаровий підігрівник 1 , сушильну камеру 2 , термосифон (ТС), конденсаційна ділянка 3 якого розташована всередині шарового підігрівника 1 , а випарна ділянка 4 розташована зовні сушарки. Конденсаційна ділянка 3 термосифону шарового підігрівника 1 виконана у вигляді торових камер 5, з'єднаних пучками труб 6 з нахилом 50...60. ${ }^{\circ}$ У корпусі сушильної камери 2 виконані канали 7 для відводу пароповітряної суміші за допомогою вентилятора 8, з'єднаного із сушильною камерою 2 .

Сушарка працює в такий спосіб. При підведенні енергії нагрівається випарна ділянка 4 термосифону. Дисперсний матеріал, наприклад зерно, надходить зверху зіштовхується 3 нагрітою поверхнею конденсаційної ділянки 3 термосифону й нагрівається до температури сушіння. Матеріал у шаровому підігрівнику 1 і сушильній камері 2 рухається щільним гравітаційним шаром. Насичене вологою повітря видаляється із сушильної камери 2 в атмосферу через канали 7 на корпусі камери за допомогою вентилятора 8. Зерновий потік рухається щільним гравітаційним шаром уздовж пучка, що $є$ конденсаційною ділянкою термосифона. Оригінальна конструкція пучка забезпечує ефективне перемішування шару зерна. Обгрунтування форми пучка проведено за результатами дослідження механіки обтікання зерном труб різної орієнтації й форми [3]. Температуру зернового потоку реєстрували за допомогою термопар. Використовувалися мідь-константанові термопари, відгра- 


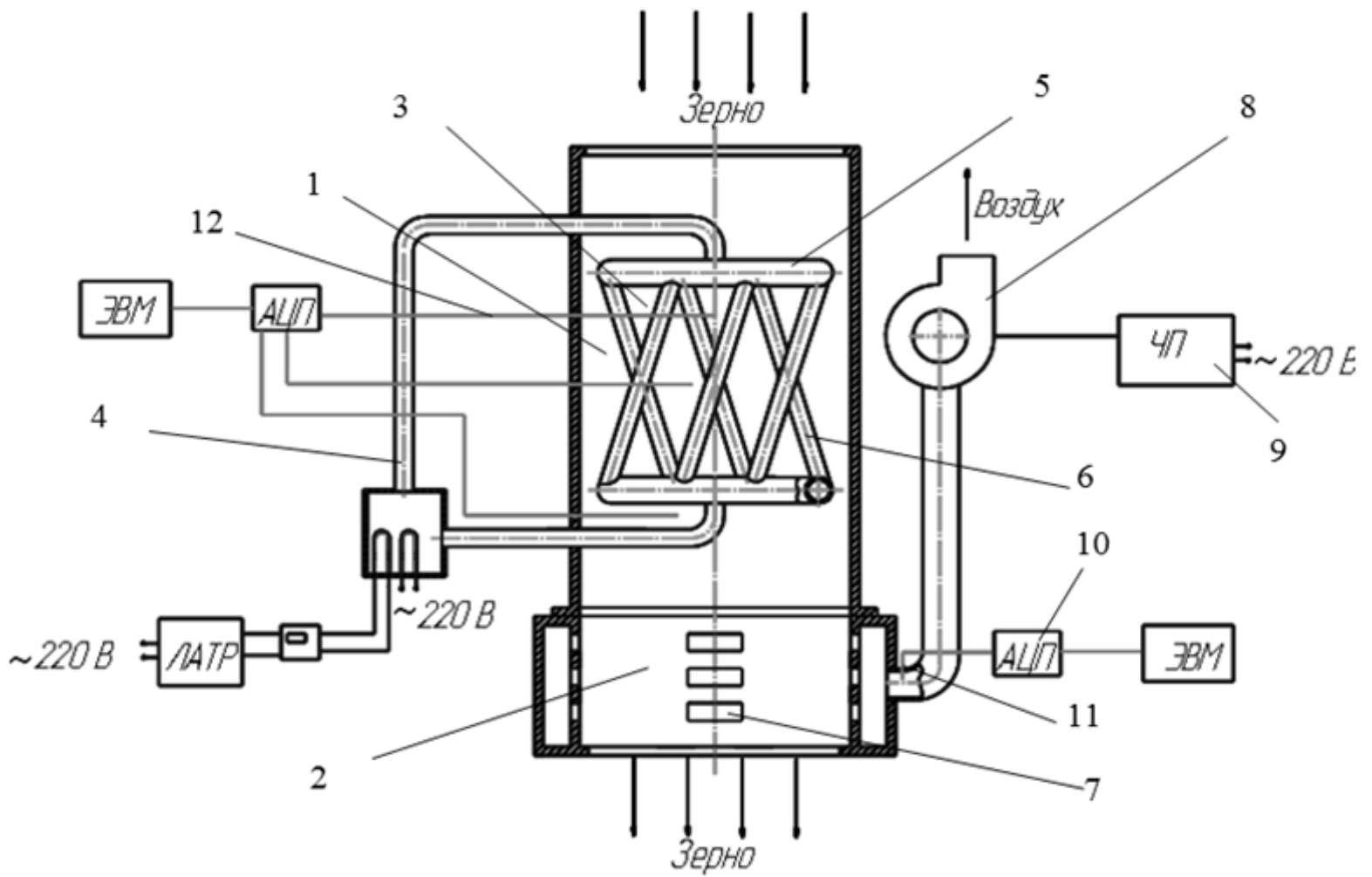

1 - шаровий підігрівник зерна, 2 - сушильна камера, 3 - конденсаційна ділянка термосифона, 4 - випарна ділянка термосифона, 5 - торові камери, 6 - пучок труб, 7 - канали для відводу вологого повітря, 8 - вентилятор, 9 - час-

тотний перетворювач, 10 - аналогово-циифровий перетворювач, 11 - датчик для виміру параметрів повітря,

12 - термопара

\section{Рис. 1 - Конструкція рекуперативної зерносушарки}

дуйовані в діапазоні температур $0 \div 100{ }^{\circ} \mathrm{C}$. Термодатчик був поміщений у капіляр діаметром 5мм і довжиною 400мм і закріплений. Кілька термопар розташовувалися по висоті сушильної шахти.

Дані первинних перетворювачів температури надходили на аналого-цифровий перетворювач (АЦП), перетворювалися в цифровий сигнал і вводилися в ПК. Інтервал реєстрації даних - 10 с.

Температуру теплоносія усередині ТС визначали по величині тиску в конденсаторі сушарки. Інтервал реєстрації даних - 600 с. У ланцюг керування

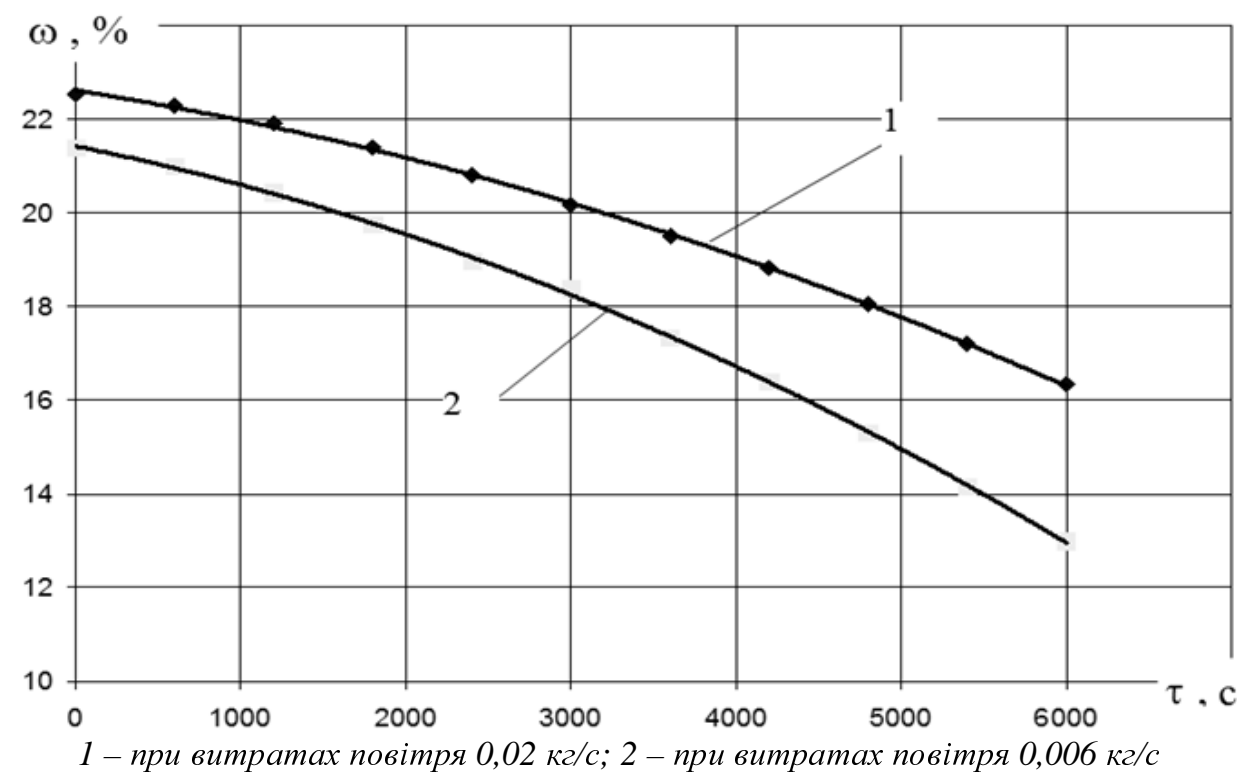

Рис. 2 - Лінії сушіння пшениці в рекуперативній зерносушарці двигуном вентилятора включений частотний перетворювач, що дозволило проводити експерименти в широкому діапазоні швидкостей повітря. У всмоктувальний патрубок вентилятора встановлений цифровий датчик вологості SHT 10 для виміру параметрів повітря - температури, вологості, ентальпії, вологовміст ту. Це дозволяло з високою точністю визначати характеристики повітря, що виходило, безпосередньо в ході експериментів. Інтерфейс програми перетворювача АЦПбув виконаний таким чином, що зміна параметрів повітря від часу відображалась у вигляді графічних залежностей $\mathrm{y}$ режимі онлайн. Використання такої схеми разом із застосуванням частотного регулювання приводу вентилятора, дозволяло оперативно втручатися в хід експерименту, спрощувало його планування. Експерименти проводили на пшениці. Вологість продукту вимірювали за допомогою цифрового вологоміру типу Wile.

Дані по сушінню й швидкості сушіння зерна пшениці в різних джерелах суперечливі. Розкид по швидкості сушіння пшениці в сушарках різного типу $0,5 \ldots 3 \% /$ хв. Це по- 


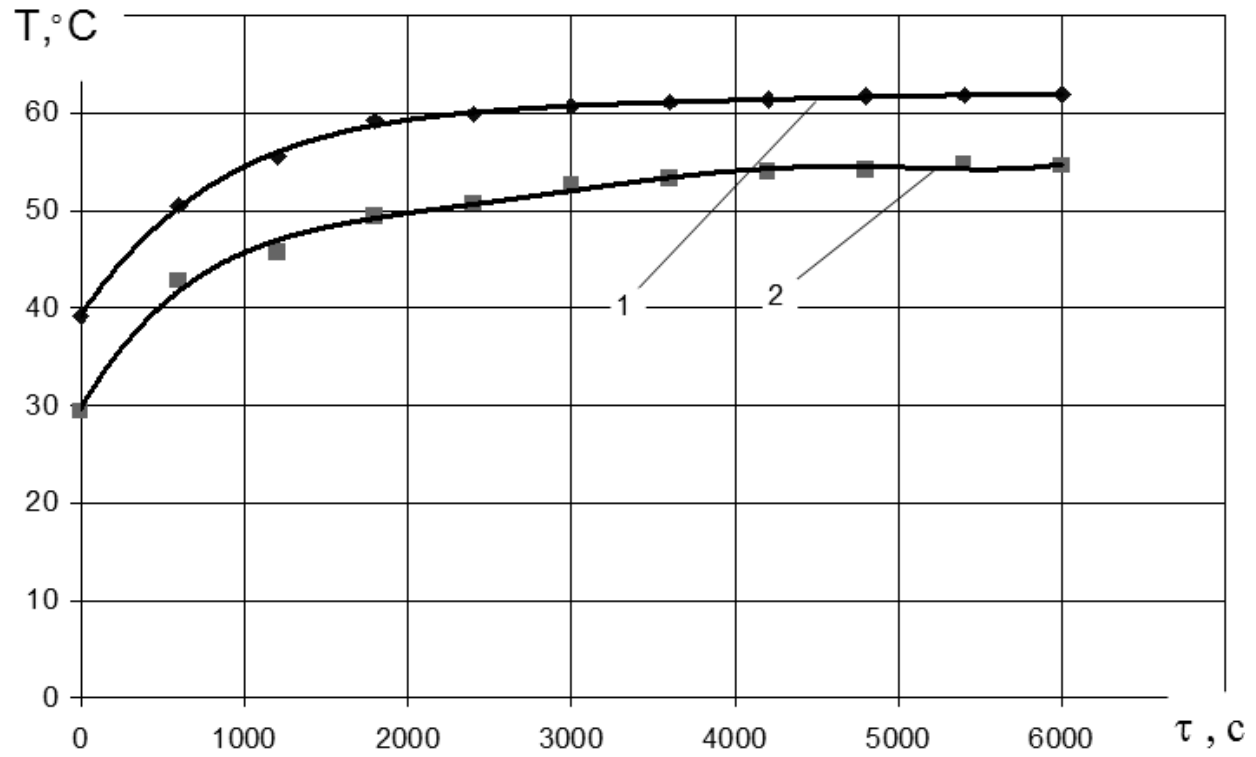

1 - при витратах повітря 0,006 кг/с; 2 - при витратах повітря 0,02 кг/с Рис. 3 - Термограми зернового потоку в рекуперативній зерносуиарці

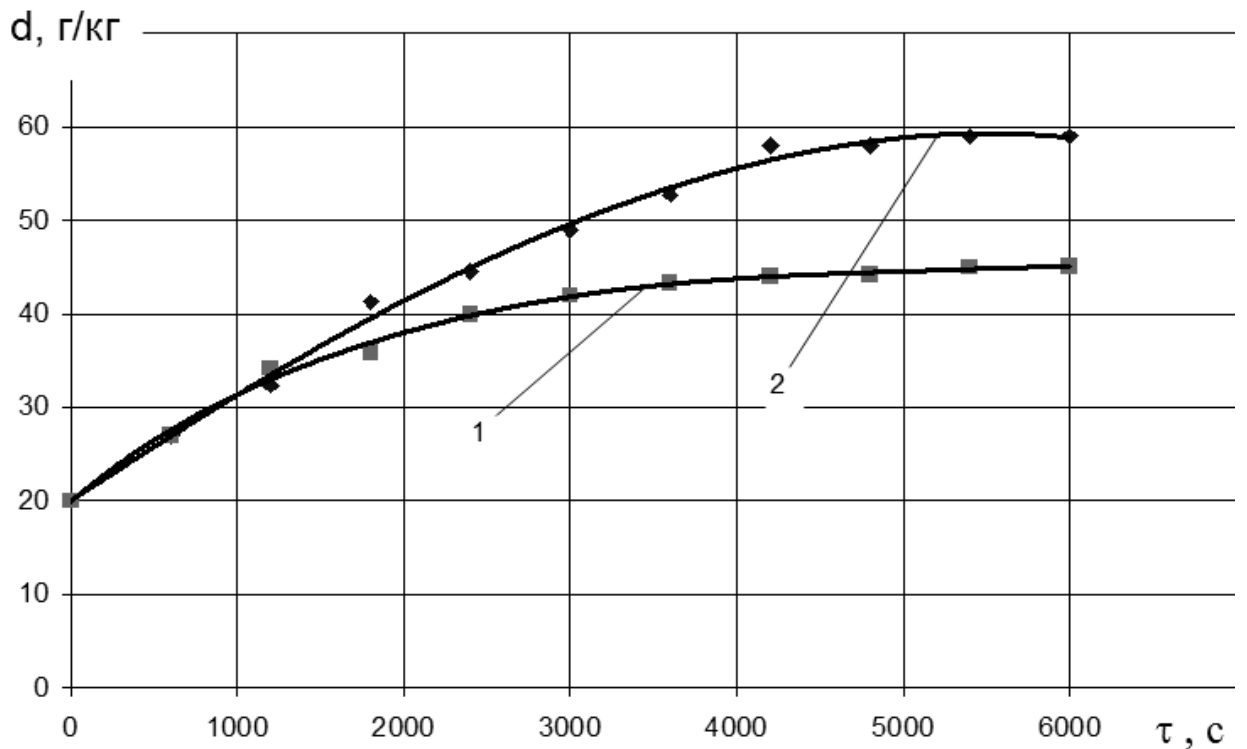

1 - при витратах повітря 0,02 кг/с; 2 - при витратах повітря 0,006 кг/с

Рис. 4 - Зміна вологовмісту повітря, щцо виходить 3 рекуперативної зерносущарки

в'язане з розмаїтістю сортів і відповідно властивостей пшениці, різною початковою вологістю, зв'язком во-

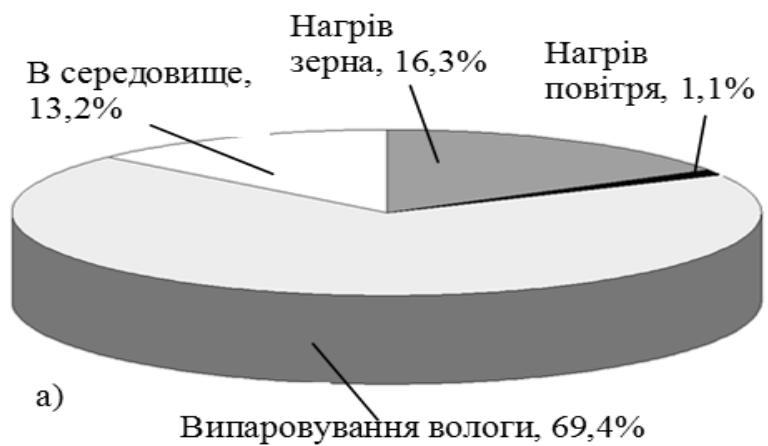

логи безпосередньо в зернівці, розмаїтістю способів сушіння. При сушінні зернових у конвективних зерносушарках присутній період постійної й падаючої швидкості сушіння [4]. У результаті експериментів отримані лінії сушіння при різних витратах повітря на виході 3 рекуперативної сушарки (рис. 2).

Після аналізу ліній сушіння й розрахунку швидкості сушіння видно, що швидкість постійно зростає й лише наприкінці процесу стабілізується. Вид ліній сушіння не характерний для сушіння пшениці в конвективних сушарках. Це пов'язане з тим, що відбувається постійний розігрів зернового потоку, що видно по термограмам зернового потоку (рис. 3).

Період нагрівання зернового потоку триває близько 3000 с, далі графіки зміни температури зернового потоку приймають практично автомодельний характер.

Температура зернового потоку стабілізується й стає рівної $50-60{ }^{\circ} \mathrm{C}$, залежно від режиму. Що приводить до нелінійної зміни вологовмісту й температури повітря на виході із сушарки (рис. 4).

Значним недоліком сучасних конвективних зерносушарок $\epsilon$ викид відпрацьованого теплоносія в атмосферу, тепломісткість якого всього лише на 10-15\% менше, ніж гарячого повітря, що подається в сушильну камеру.

Нагрів

$25 \%$ В середовище, вологи, 20\%

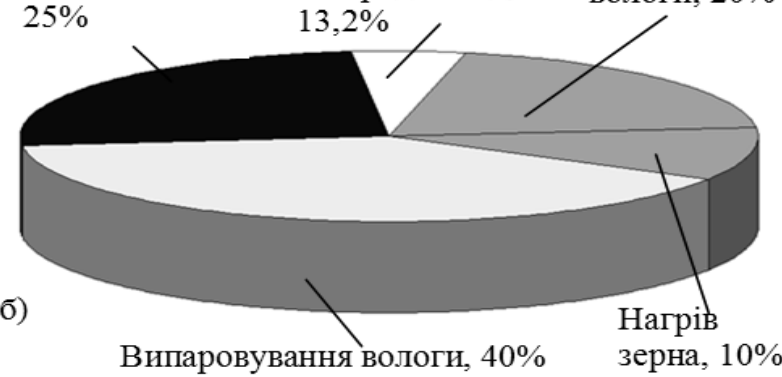

Випаровування вологи, $40 \%$ зерна, $10 \%$

а) рекуперативна, б) конвективна

Рис. 5 - Розподіл теплової енерхї̈ в зерно сушарках 
У порівнянні із шахтною конвективною зерносушаркою ДСП-32, повітря на виході з рекуперативної зерносушарки має набагато більшу вологість i вологовміст що робить його близьким до точки фазового переходу. При витраті повітря 0,006 кг/год, вологовміст повітря наприкінці процесу сушіння становив d=60 г/кг при відносній вологості 94\% (у порівнянні із ДСП 32, d=24 г/кг). Крім того витрати повітря в конвективних сушарках і рекуперативній відрізняються на порядки. Для оцінки розподілу енергії в рекуперативній зерносушарці, складене рівняння теплового балансу. Після аналізу експериментальних даних одержуємо, що в порівнянні з конвективним сушінням у рекуперативної сушарки більша частина енергії $(69,4 \%)$ затрачається на випаровування вологи, на нагрівання зерна 16,3\%, втрати в навколишнє середовище 13,2, на підігрів повітря всього близько $1,1 \%$ (рис. 5).
В рекуперативній зерносушарці з випаруваною вологою й повітрям втрачається більше $50 \%$ підведеної енергіï, іiі утилізація дозволить значно знизити енерговитрати сушарки, збільшити її ККД.

Для цього необхідно зробити розрахунок теплообмінника рекуператора для утилізації теплоти вологого повітря, що виходить з сушарки.

Аналіз параметрів відпрацьованого повітря рекуперативної зерносушарки, показує, що з'являється реальна можливість використання тепла конденсації вологого повітря для попереднього нагрівання зерна.

Завдання подальших експериментів - у теплообміннику - рекуператорі підігріти зерно до сушіння за рахунок енергії повітря, що викидається. За таких умов з'являється можливість повернути в зерновий потік значну частину енергії, що була витрачена в сушильній шахті.

1.Бурдо, О.Г. Эволюиия сушильних установок [Текст] / О.Г. Бурдо, // Монография / - О, Полиграф, 2010. - 368 с.

2. Современное состояние и тенденции развития мощностей по хранению зерна в хозяйствах Украины, Журнал «Хранение и переработка зерна» : http://hipzmag.com/

3.Бурдо, О. Г. Кінетика сушіння пшениці в апаратах на базі термосифонів [Текст]/ О. Г. Бурдо, I. В. Безбах, В. I. Донкоглов // Наук. пр. /ОНАХТ. - О., 2009. - Вип. 36, m. 1. - С. 297-302.

4.Гинзбург, А. С. Влага в зерне [Текст] / А.С. Гинзбург, В. П. Дубровский, Е. Д. Казаков- М.: Колос, 1969. - 217 с.

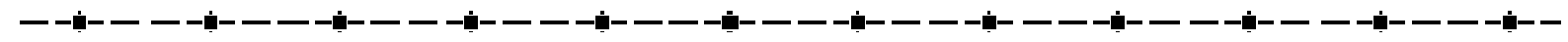

УДК 664.723.047.59

O.G. Burdo, D. Sc., professor, head of processes, apparatuses and energy management department,

I.V. Bezbakh, Ph.D., doctoral student,

A. Zykov Ph.D., docent of processes, apparatuses and energy management department

Odessa National Academy of Food Technologies

\section{RESEARCH OF THE DRYING PROCESS IN THE RECUPERATIVE GRAIN DRYER}

The existing drying equipment is analyzed. It is shown that the problem of reducing of the energy consumption of drying can be solved through targeted delivery of energy to the grain. The thermosiphon-based devices for dispersed food materials drying are considered. The construction of the regenerative dryer, which implemented targeted delivery of energy to the grain by heat pipes, is presented. The original design of the heat pipe condensing section provides both the effective energy transfer to the layer of material and the effective mixing of it. The results of regenerative grain dryer experimental studies are presented. Our results revealed that the shape of the curves is not typical for drying of wheat in convective dryers. Due to the constant grain flow heating, the drying rate is constantly growing, until the end of the process when it stabilizes. Analysis of moisture and air temperature at the outlet of the dryer shows that the recuperative dryer outlet air has a much higher relative humidity and moisture content than the DSP-32 outlet air, which makes it close to the dew point. In addition, the air rate in convective dryers differs from the air rate in the recuperative dryer more than ten times. After analysis of the heat distribution in dryers, it is revealed that unlike convective drying in the recuperative dryer the most of the energy (69.4\%) is spent on evaporation, which confirms the more efficient use of energy in recuperative dryer. The analysis of parameters of exhaust air of the recuperative dryer shows there is a real possibility to use the heat of condensation to preheat the grain. Thus, it is possible to return to the grain flow a significant portion of energy that was spent in the dryer.

Keywords: thermosiphons, particulate materials, grain drying, energy efficiency.

\section{REFERENCES}

1. Burdo O.G. Evolution of dryers [Text] / O.G. Burdo // Monograph / - O, Polygraph, 2010. - 368.

2. Modern condition and development trends of grain storage facilities in the economies of Ukraine, The magazine "Grain storage and processing»: http://hipzmag.com/

3. Burdo O. G. Kinetics of wheat drying in thermosiphon based devices [Text] / O.G. Burdo, Bezbakh I.V., V.I. Donkoglov // Scientific works. /ONAFT. - O. 2009. - Issue. 36, vol. 1. - P. 297-302.

4. Ginsburg, A. Moisture in grain [Text] / A. Ginzburg, V.P. Dubrovsky, E.D. Kazakov-M.: Kolos, 1969. - 217. 